\title{
Social media and political narratives: a case of Zimbabwe
}

\begin{abstract}
This paper discusses Social Media's role in Zimbabwe's political unfolding. The paper will trace the history of social media in Zimbabwe from the early period of Baba Jukwa towards the July 2013 harmonised election. Cases like that of Itai Dzamara, Pastor Evan Mawarire and their impact on the Zimbabwe populace and the social media audiences in particular will be discussed. It will also look at the period before, during and after the July 312018 'controversial' harmonised elections and the subsequent events that followed after the election. The paper argues that social media played a critical role in narrating the events as they unfolded. The role played by social media cannot be underestimated as it, to a greater extend influenced certain remarkable decisions by the politicians and all the political key players. The article will highlight remarkable shifts in information dissemination and even information acquisition brought about by the coming in of social media, especially on the periods in question. The paper argues that social media brought a monumental shift which ushered in citizen involvement and robust engagements and discussions which changed people's perception of politics. This article will look at the good side and the ugly side of this shift, detailing how social media violated media ethics, exposed people to marauding opponents and how in certain instances was used as a tool to spread fake news. The paper also seeks to highlight how Cyber Warfare became prominent on various social media platforms, with proponents mainly choosing to hide behind 'Ghost accounts' while some used their correct credentials to amass attention and get personal political mileage through spreading biased narratives, fake news and factualized opinions. The paper will, through citing certain social media players' accounts lay bare the effect of this tool and show where it poses as a threat as well as where it was and is an opportunity for the Zimbabwean community. The paper argues that social media changed lives, perceptions and convictions; it enlightened some while it created fanatics in others.
\end{abstract}

Keywords: social media, Facebook, Twitter, alternative public sphere, democracy
Volume 3 Issue 3 - 2019

\author{
Teddy Mungwari,' Alfred Ndhlebe ${ }^{2}$ \\ 'Department of Language \& Communication Studies, Chinhoyi \\ University of Technology, Zimbabwe \\ ${ }^{2}$ Department of Digital Archivist, university of Zimpapers, \\ Zimbabwe
}

Correspondence: Teddy Mungwari, PhD, Senior Lecturer, Chinhoyi University of Technology, Zimbabwe Centre for Language \& Communication Studies, Zimbabwe, Email teddymngwaril@gmal.com

Received: April 25, 2019 | Published: June 13, 2019

\section{Introduction}

The coming in of the Movement for Democratic Change (MDC) in September 1999 changed the political landscape; it challenged the political narratives of the land. The MDC as a political party wanted to spread their ideology to Zimbabweans so as to get supporters and challenge the ruling party the Zimbabwe African National Union Patriotic Front (ZANU PF) in the 2002 election. ${ }^{1}$ The opposition political party had so many hurdles reaching the electorate mainly due to hostility and rigidity from the state controlled mainstream media entities in the country. The Zimbabwe Broadcasting Corporation (ZBC) - a state controlled entity could not give MDC some air play or at least some coverage despite the Zimbabwean Constitution Election regulations on the media which state that stations of a public broadcaster shall allocate four hours of available purchasable airtime during an election period for election advertisements, which shall be distributed, equally to political parties and candidates contesting the election in question. The coverage from both state owned television and radios were only demonising the opposition movement in an attempt to discourage people from supporting and even liking the outfit. The Zimbabwe newspapers (Zimpapers) also took the same stance; the opposition would only get negative publicity. It is at this time that the state's control of all information outlets was exposed. The deliberate failure of the state to separate politics and nation-serving was tested and found wanting. ZANU-PF interests took precedence over national interests, the opposition was a threat to ZANU-PF's political shelf-life and the only option was to make use of state apparatus to suffocate any publicity attempt.
Private media emerged, with the coming in of Daily News in 1999 and Joy TV around the 1997. These entities were game-changers in that they started giving the opposition space and coverage. They helped the opposition penetrate into the electorate; the entities took advantage of people's trust for newspapers and televisions as well as radios. Actually the Daily News was accused of being the opposition's mouth-piece by Robert Mugabe. These had fed them with information during the liberation struggle; stations like radio Maputo had helped the Zimbabwean war fighters communicate their agenda and ideology with the mass. The Zimbabwean community up to this day believe so much in radio and television stations as well as newspapers, thus the Daily News gained ground and had significant penetration into rural areas and towns. The state's entities were greatly exposed for their biased and negative coverage of the opposition and they lost a huge audience. Bad policies by the government worsened the situation. The Daily News gave people what the state controlled entities could not, people felt cheated and short-changed, they were determined to vote ZANU-PF out of power. The independent media gained popularity and support; the state could not censor nor stop it, because by this time, there were no legislative provisions against it.

Election 2000 and the Referendum of 2000 showed the state that people had fed on the opposition ideology propounded by the 'independent' or private media channels. The political transformation was great, it gave ZANU-PF political scars after a historic near-lose and controversial election. Private media had informed voters. The narratives of the chaotic fast track land reform program with its horrific incidents were widely covered by private media thus allowing people 
an opportunity to see the failures of the ruling party. The private media fought to give people candid news and information which the state owned media outlets was sugar coating to favour ZANU-PF. Heinous acts of political violence on perceived opposition political opponents were exposed, a lot was exposed and the ruling party was in danger People had information and they grew to dislike anything associated with ZANU-PF. Several attempts by suspected state mechanisms to silence the independent media, especially the Daily News began to sprout. The damage was too much and the paper had to be closed, but there were no legislative grounds for this action. The printing press of the Daily News was bombed by suspected state sponsored activists. Expensive equipment was destroyed; the vandalism was great and forced the newspaper to close its operations. While it was recuperating, the state through the Ministry of Information which was under Professor Jonathan Moyo started to craft vices and putting in place laws which would make it difficult if not impossible for independent media to operate in the country. Joy TV under James Makamba was also affected and got closed on May 31 2002, leaving airwaves exclusively to ZBC, while the print media was being dominated by Zimpapers and other mild independent papers like The Independent and Financial Gazette, Daily News had to endure a decade in hibernation. The state controlled broadcaster ZBC indicated that it could no longer renew Joy TV's operating license stating some operational breaches by the television station.

The shutting of independent media channels through legislature meant that the whole country was to feed from one feeding trough which was ZBC and Zimpapers products. This, for people who had tasted independent media news was a thorn in the flesh. The remaining media channels were controlled, censored, manipulated and biased. Media was strictly monitored because of its influence in people's decision making, especially on every election since the coming of the MDC in 1999. The strive to bring news by independent media also led to the launch of Studio 7 Radio in 2004, which was launched in Washington DC and could be accessed by Zimbabweans everywhere on their radios. This too was greatly abhorred by the state and ruling party politicians. They accused this radio station for peddling falsehoods to further what they called the regime change agenda. This radio station was the main media channel that gave people news towards the 2008 election. Reports state that DSTV in the towns and Studio 7 mainly in rural areas became so popular. In some cases, villagers would meet around a radio in the evening to get updates from Studio 7. The politics in Zimbabwe created a people who wanted to know beyond what their authorities would want them know and to say beyond what was permitted. Their challenge was the restrictions put up by the state as well as the limited or constricted platforms available to do this.

\section{Historical background}

$\mathrm{Moyo}^{2}$ notes that the use of social media for purposes of civil resistance is largely associated with the 2011 "Arab Spring" which was witnessed in countries such as Tunisia, Egypt, Bahrain, Syria, Libya, Jordan, Morocco, Algeria, Yemen, Oman, and Djibouti. Chiluwa $^{3}$ notes that, during the Arab Spring, generally, planning and discussions were carried out on Twitter and Facebook where activists talked to each other, mobilized protesters and advanced new strategies. The UK was also not spared from social media related protests organized by students. "The violent protests in the United Kingdom (UK) from July-August 2011 were also driven through Twitter, Facebook and BlackBerry Messenger". ${ }^{4}$ In terms of political change and impact, the UK case comparatively falls below the "Arab Spring." In North Africa, the Tunisian, Egyptian and Libyan cases were outstanding as they led to dramatic and radical changes. In the Tunisian scenario, which sparked the Arab Spring, social media allowed the formation of networks by the "digital elite"; reporting on the magnitude of protest events; and the facilitation of the formation of a national collective identity which transcended geographical and socio-economic disparities. ${ }^{5}$ One Egyptian activist during the Egyptian revolution said: "We use Facebook to schedule the protests, Twitter to coordinate, and YouTube to tell the world . ${ }^{6}$ In Libya, Harvey $^{7}$ acknowledges social media use during the Libyan revolution but dispels the notion that it was a "Twitter or Facebook revolution" due to low levels of internet penetration in Libya at that time.

Importantly, Chiluwa ${ }^{3}$ notes that, "the North African revolutionary experience, with its huge implications for the rise of new paradigms for political change and government, demonstrates the potential for similar uprisings, not only in the Muslim world but also in other parts of Africa." Chiluwa's remarks hold water considering the emergence of social media related platforms in Sub-Saharan Africa in recent years. Correspondingly, Willems ${ }^{8}$ notes that the \#GoToVote campaign which seeks to mobilize people to vote in peace has gained ground in Kenya. The Southern African region cannot be excluded from the narrative of social media related political participation. By the same token, Willems ${ }^{8}$ notes that, social media platforms - primarily Facebook, WhatsApp and to a lesser extent Twitter-also played an important role in circulating information during the recent Zambian elections. In South Africa, March 2015 witnessed the birth of the \#RhodesMustFall protest movement. The describe the \#RhodesMustFall movement as: "a wave of student protests that started at the University of Cape Town (UCT), South Africa, with the purpose to 'decolonize' the University and rid it of offensive colonial symbols such as the statue of Cecil John Rhodes." Importantly, in relation to this paper, Klemenčič emphasise on the importance of social media; mainly Twitter in the articulation of messages by the \#RhodesMustFall movement. Additionally, in October 2015, the \#FeesMustFall protest movement, which advocates free tertiary education in South Africa, also emerged. In Zimbabwe, economic collapse, poor service delivery, former President Mugabe's advance age and ill-health led to the birth of civil resistance and the emergence of social and citizen movements. Moyo ${ }^{9}$ notes that, government's corruption in Zimbabwe has stirred a deadly pot of stark civil resistance and disobedience and the birth of social movements and campaigns such as \#ThisFlag, \#ThisGown, ${ }^{10}$ \#ThisFlower and \#Tajamuka/Sesijikile.

This article therefore seeks to assess how these social movements used social media in their resistance against the ruling party (ZANU PF) and government in Zimbabwe from 2013 to 2018. Also, the paper embarks on a stock taking exercise to ascertain the effectiveness of the use of such social media platforms by the afore-mentioned groups. There is inadequate literature on this area of study particularly in relation to Zimbabwe. Most studies tend to focus on social media in relation to the "Arab Spring" or South Africa's \#RhodesMustFall and \#FeesMustFall movements. Zimbabwe as a case study has not been adequately and exhaustively covered. This study therefore seeks to fill that scholarship gap by examining the use of social media (for civil resistance) by social movements in Zimbabwe. The new wave of social media political activism which was ignited by Pastor Evan Mawarire's \#ThisFlag movement in 2016, raised curiosity and motivation for the undertaking of this research. Besides, social media related social movements and campaigns in Zimbabwe represent "a 
third political force" outside government and political parties and therefore a phenomenon worth investigating.

\section{Social media as political public sphere}

Gukurume ${ }^{10}$ opine that in the Zimbabwean context, social media can be contextualized as an alternative counter public sphere or a subaltern public sphere-a space where the constraints and surveillance of an authoritarian state are circumvented. Through social media, counter discourses in the mainstream public sphere are produced, reproduced and articulated. For Fraser, ${ }^{11}$ social media are spaces for incubating dissent towards the mainstream or conventional publics. Similarly, Squires ${ }^{12}$ notes that counter publics are spaces that stimulate debates, planning and mobilisation. Since the popular Arab Spring, there has been an upsurge of research on the role of social media for political mobilisation. Gukurume ${ }^{10}$ argues that social media has been harnessed to make political demands on human rights, accountability and good governance, in particular in Africa. A huge body of literature focuses on how youths have appropriated social media platforms as an alternative form of political activism. ${ }^{13-15}$ Some growing body of scholarship has also focused on the complex ways in which social media and political participation are entangled in African contexts. ${ }^{16-18}$ Most of these scholars argue that political movements are actively harnessing new social media technologies as an orchestration and mobilisation of their political activities. Further, some scholars also explored how politicians are creatively appropriating social media technologies as an election campaigning strategy to reach out to the youth and other prospective voters. ${ }^{19-22}$

It should be noted that cyber-activism is not in any way new in Zimbabwe. After arguably the most violent election in the post-colonial history of the country in $2008,{ }^{23}$ many people resorted to disseminating and voicing their tribulations through blogging. ${ }^{24}$ Moyo's ${ }^{23}$ study focused on Kubatana - a civic organisation active in online activism through disseminating cases of human rights violations throughout the country. Indeed, civil society organisations have been at the centre of the protest movement in Zimbabwe, especially the student unions ${ }^{25,26}$ and workers' movements. ${ }^{27}$ In their study, Mutsvairo \& Sirks ${ }^{15}$ argued that although people were encouraged to engage in everyday political talk through open political discussions and sharing thoughts on a Facebook page called Baba Jukwa, it is still debatable whether these engagements translated into active political participation. Likewise, $\mathrm{Chiumbu}^{28}$ argued that while social media provide a space for these movements to project and disseminate counter hegemonic narratives and ideologies, such spaces are fraught with power dynamics, which militate against their morphing into physical political activism. Gukurume's ${ }^{10}$ study explored on the \#ThisFlag citizen movement in Zimbabwe and the \#ThisGown movement that emerged through social media from April 2016 to challenge ZANU PF government. Gukurume ${ }^{10}$ showed how this movement 'reawakened the voices of Zimbabweans who had been silent and suppressed by the Mugabe government for quite a long time through the state security agents sniffing and spying on ordinary citizens who could be anti-Mugabe'. Gukurume's ${ }^{10}$ study concluded that the power of social media as a political tool in Zimbabwe has become far more important as seen particularly with the \#ThisFlag citizens' movement and other hashtag movements in the country. As such, the overwhelming popularity of the \#ThisFlag movement shows that social media plays a fundamental role in mobilising political action and creating networked transactional publics that can be vehicles of political change. ${ }^{29}$ Gukurume ${ }^{10}$ argues that the Zimbabwean people have utilised social media through the
\#ThisFlag movement to reclaim their political space and voice, as noted by the leader of the movement, Pastor Evan Mawarire, through this campaign the of Zimbabwe have scaled the deep-seated walls of their fear and political quietness. His conclusion resonates with Mare ${ }^{14}$ who argues that social media like Facebook should be understood and conceptualised as alternative discursive spaces of political engagement for the marginalised groups, the so called subaltern.

This article explores the use of social media platforms, mainly Facebook, WhatsApp, and YouTube for the purposes of civil resistance by social movements in Zimbabwe from 2013 to 2018. The social media movements under study include: \#ThisFlag, \#Tajamuka/ Sesijikile, \#OccupyAfricaUnitySquare, \#ThisGown and \#ThisFlower. Although there is literature on social media movements in Zimbabwe, this study is inspired to bridge the scholarship gap by exploring how social media platforms were used for civil resistance during the period under discussion, that is, from 2013 to 2018.

\section{Methodology}

In terms of sources of information, the article relied on Facebook, WhatsApp, Twitter, and YouTube accounts of the social movements in question in Zimbabwe. Therefore, the authors closely followed social media accounts of the \#ThisFlag, \#Tajamuka/Sesijikile, \#ThisGown, \#OccupyAfricaUnitySquare and \#ThisFlower movements. The researchers analysed the audio-visual and textual content by these social movements from their social media accounts. In addition to that, newspaper articles, journals, reports, and various internet sources played an important role for the purposes of data collection for the article. The correspondent author also utilized observation as he attended the trial of Pastor Evan Mawarire at the magistrate court. It is during this period that the researcher witnessed many activities (including street protests) by these social movements. In addition to that, the authors had informal discussions with some members of the social movements under study. Although there are several social movements in Zimbabwe, this article's focus is biased towards \#ThisFlag, \#Tajamuka/Sesijikile and \#OccupyAfricaUnitySquare movements as well as Baba Jukwa. Other movements will be highlighted but not in detail. The period of study for this article is 2013 up to 2018 . However, partial reference to January 2019 is done only to highlight the arrest of Pastor Evan Mawarire by President Mnangagwa's administration. Also, the period before 2013 will only be used for reference purposes. The study period ends in 2018 a year after former Zimbabwe's President, Robert Mugabe, was overthrown in a popular military coup in Zimbabwe.

\section{Theoretical trajectory}

This section focuses on theoretical paradigms that are associated with social media. To this end, this section discusses the social penetration and social exchange theories in relation to this study. The social penetration theory is summed up in the following words: The social penetration theory suggests that relationships become more intimate over a period of time when more personal information is revealed. This is evident in Twitter relationships. Millions of friendships have formed from "tweet-ups" as a friend request. A person may start to follow you but constant and direct interaction will lead to more intimate friendships that go beyond computer and cell phone. Maintaining relationships also relies on intimate exchanges by both parties. ${ }^{30}$ In this regard, the social penetration theory is relevant to this article considering the relationships that have been created (over time) on social media networks by social movements in Zimbabwe. The 
fact that the relationships between the leadership of social movements and their followers has graduated from existing on online platforms to physical space, rhymes with the dictates of the social penetration theory. Moreover, social and citizen movements in Zimbabwe have managed to penetrate societies through social media platforms. ${ }^{2}$

Another important theory is the social exchange theory, Emmerson as cited in Pan B, ${ }^{31}$ notes that the social exchange theory states that human beings form close relationships through self-disclosure. Social exchange theory originated from sociology studies exploring exchange between individuals or small groups. ${ }^{31}$ Furthermore, Homans in Pan \& Crotts $^{31}$ observes that the social exchange theory mainly uses cost-effective framework and comparison of alternatives to explain how human beings communicate with each other, how they form relationships and bonds, and how communities are formed through communication exchanges. ${ }^{31}$ The theory states that the individuals engage in behaviours they find rewarding and avoid behaviours that have too high a cost..$^{31}$ It could therefore be argued that citizens in Zimbabwe are making relations on social media because of the beneficiary nature of such a relationship. Moreover, such a relationship could lead to good governance in the future (if there is political will) which is beneficiary to social media political participants in Zimbabwe. Thus, it is important to underline that the social penetration and the social exchange theories blend well with social media related and social movements not only in Zimbabwe but all over the globe. ${ }^{2}$

\section{Pastor evan mawarire background}

Pastor Evan (full name Evan Mawarire) is a Zimbabwean political activist, politician, religious leader, Motivational Speaker, author and leader of the \#ThisFlag Movement. In April 2016 he posted a video on Facebook with the title \#ThisFlag which went viral spurring the start of the \#ThisFlag hashtag online. He was arrested in July 2016 after successfully calling for a national 'Stay Away' dubbed '\#Shutdown Zimbabwe' and he was charged of treason but later acquitted in November 2017 following a coup that ousted former president Robert Mugabe from power. In January 2019, he was arrested again following the 3-day Zimbabwe Congress of Trade Unions (ZCTU stay away which he had supported publicly. The stay away protests had turned violent with retail shops looted and many vehicles burnt. He was charged again with treason on 17 January 2019. Evan Mawarire was born on March 7, 1977. He is married to Samantha Mawarire and they have two daughters. He did his secondary education at Prince Edward High School in Harare. Mawarire is a qualified auto electrician from the Harare Institute of Technology. Mawarire served as Child President between 1993 and 1994 after having been elected child MP for Mashonaland West Province constituency. He was based in London England, as the Regional Director for Celebration Ministries International for Europe and the Asia Pacific Rim from 2007 to 2010. In 2011 he was chosen as one of Zimbabwe's 10 Outstanding Young People by the Junior Chamber International for moral leadership.

\section{This Flag campaign}

On 20 April 2016, Pastor Evan posted a video on Facebook titled ThisFlag in which he decried the state of the economy and how he felt Zimbabwe was not delivering its promises to its citizens. The video went viral on Facebook (where it got more than 100,000 views) and WhatsApp. The \#ThisFlag movement, which describes itself as a "citizen movement" was started by a Zimbabwean Pastor Evan Mawarire in May 2016. Aljazeera ${ }^{32}$ notes that, Pastor Mawarire is heralded as the initiator of the rise of social media activism, with an online monologue discussing the "violations" of the Zimbabwe flag. Moreover, "The video created a domino effect, launching an ongoing campaign using the hashtag \#ThisFlag, used as a means of protesting about Robert Mugabe government". ${ }^{32}$ The \#ThisFlag campaign mainly uses the Zimbabwean flag as a symbol of resistance. Mawarire with a flag wrapped around his neck, started posting videos which bemoaned government corruption, national leadership ineptitude and poor service delivery. His videos went viral and he was joined by scores of Zimbabweans in the country and diaspora.

The \#ThisFlag movement is mostly dominant on Twitter, Facebook and WhatsApp. The movement also uses YouTube and Instagram. ${ }^{2}$ As of 25 February 2017, the \#ThisFlag Facebook page had 59649 followers $^{33}$ and 63000 followers on its twitter handle. The \#ThisFlag movement has a large support base of Zimbabweans in the diaspora, mostly in the UK, US, Germany, South Africa and Australia, among other countries. ${ }^{2}$ An observation shows that, on social media platforms, the movement's activities includes; issuing of statements, updates, hosting interviews with national leaders, mobilisation and recruitment. Apart from online activities, the \#ThisFlag movement also participates in protests on the streets ${ }^{10}$ and at Zimbabwean embassies in foreign countries like SA, UK, USA, and Germany. ${ }^{2}$ Moyo (ibid) notes that supporters of the \#ThisFlag movement are from diverse backgrounds sections of the society; business, church, student movements, intellectuals, journalists, women's groups, and youth organisations, among others. Gukurume ${ }^{10}$ opine that the \#ThisFlag morphed "from virtual to the physical: \#ThisFlag online and offline protests". He further argues that there was a transition from the "cyber space" to the "physical space' (p. 56). For more details on other hashtag movements such as \#Tajamuka/Sesijikile, \#OccupyAfricaUnitySquare, \#ThisGown and \#ThisFlower. ${ }^{2,10}$

\section{Government's response to the \#This Flag}

Gukurume ${ }^{10}$ posits that realising the political threat posed by the \#ThisFlag and \#ThisGown movements, the government responded in a myriad of ways. Some of the responses to intimidate protesters included threats and actual acts of violence, arrests, and the deployment of the police and youth militia. Gukurume ${ }^{10}$ argues that the responses deployed by the government to counter the protests give credence to Mitra' ${ }^{34}$ observation that subaltern ${ }^{35,36}$ and marginalised voices in society posses as great potential to indirectly speak truth to those in power, who are in turn morally obliged to hear their voices and possibly recognise them.

The most prevalent strategy to crush the protests was the wanton arrests of the protest organisers-a fate that fell on the leader and founder of the \#ThisFlag movement, Pastor Evan Mawarire and some \#Tajamuka/Sesijikile members such as Promise Mkwananzi and Linda Masarira. After the arrest, Masarira was detained for months before being released. Although Pastor Mawarire always insisted on peaceful and non-violent protests against the government since the movement was launched in April 2016 (as evidenced by his videos and all messages he posted on social media platforms), he was arrested on 10 July 2016 when he handed himself to the police for questioning. $\mathrm{He}$ was initially charged with inciting public violence. However, during his hearing at the magistrate court, the charges changed to a more serious one of attempting to subvert a constitutionally elected government-a charge tantamount to treason in Zimbabwe. In the early morning of the court case, thousands of people, including the 
main correspond of this article, converged the court in solidarity with Pastor Mawarire. This article argues that since independence there is no one who has been represented by lawyers in Zimbabwe like Pastor Mawarire. Competent human rights lawyers thronged the magistrate court; and many international journalists covered the situation.

After being denied entry into the courtroom, the people spent the whole day outside the courts. With flags hung on our necks, people sang church hymns and revolutionary songs, people danced, joked and laughed and more importantly, we prayed as we waited for the court ruling. The atmosphere was tense and the mood was both sombre and triumphant. The judges deliberately attempted to delay the case in the hope that people would disperse, but the people only multiplied with each passing hour-people soldered on outside the intimidating magistrate court, enduring the heat and the heavy presence of armed police officers who looked menacingly at people. It was only around 2.15am that the court adjourned and Pastor Evan Mawarire's charges were dismissed and he was released to the thunderous applause. There was ululation and more victorious singing befitting a hero as he made his way out of the courtroom to address the people waiting outside. Social media such as WhatsApp and Facebook were awash with videos of his release.

However, only a few days after his release and departure to South Africa where he addressed Zimbabwean students at several universities, President Mugabe accused him of inciting violent protests against his government. While addressing people at the national Heroes' Acre during the state funeral of his aide, Dr Utete, Mugabe took the opportunity to directly threat Mawarire. ${ }^{10}$ In his speech, Mugabe drew on his traditional rhetoric in framing Pastor Mawarire as a foreign - funded agent of regime change. In that statement, Mugabe did not only label Mawarire a traitor and sell-out, but also questioned his citizenship and belonging. In asserting that people like Mawarire do not deserve to belong to Zimbabwe, Mugabe invoked his favourite "patriotic history" narrative of separating "patriots" from "sell-outs". 1,37,38 Ironically, while Mugabe derided Mawarire's religious standing and citizenship, the rallying ideology of the \#ThisFlag movement is also embedded in the very same discourses of citizenship and belonging - that citizens have to speak out and act for a better and prosperous Zimbabwe (which Mugabe had destroyed). This discourse of Mawarire was also captured by private media, particularly Daily News, News Day, The Zimbabwean and The Standard, among others. However, state media which is captured (see Mungwari, ${ }^{23}$ article titled "The Politics of State Capture in Zimbabwe") labelled Mawarire and other activists as "dissidents: and "cyber terrorists". Gukurume ${ }^{10}$ argues that this denigrating discourse coincided with the emergency of anti-Mawarire slogans used in political campaigns by ZANU PF officials.

Further, ZANU PF also responded to the protests by organising their counter protests led by their youth league and militia. ${ }^{39}$ For instance, after the \#ThisFlag organised a national stay away named \#Shutdown on 6 July 2016, the ZANU PF youth league organised a counter march in support of the president in Harare on 20 July 2016 (a phenomenon embraced by ZANU PF each time a president is challenged). At these counter protests, ZANU PF politicians like Joseph Chinotimba and Psychology Maziwisa among others took turns to chant slogans denouncing Pastor Mawarire. ${ }^{10}$

\section{The Internet access}

Zimbabwe Freedom House report (2015) states that Zimbabwe's internet access is expanding incrementally, growing from a penetration rate of 19 percent in 2013 to 20 percent in 2014, according to estimates by the International Telecommunication Union (ITU). Advances in technology saw a rise in the use of cell phones and computers in Zimbabwe. This rise was fuelled by the use of internet on these devices, which enabled people to get a wide access on news and any type of information posted on the internet. The digitization of operations by news channels also saw a shift from traditional broadcasting to new forms such as video calling, Live feeds, and live streaming among other advanced operations. This meant that access to independent news in the country was now made possible. The state could no longer manage to strictly control what the general public would access through internet on their devices. By contrast, official government statistics report an internet penetration rate of 50 percent as of December 2014, up from 42 percent in 2013, which includes both fixed-line and mobile internet subscriptions. Approximately 99 percent of internet access is via mobile telephones, while access via fixed-line internet remains low at less than 1 percent. The mobile phone penetration rate, which is over 100 percent, includes users with multiple SIM cards, thus belying the actual number of Zimbabweans who have access to mobile services - estimated at only 60 percent. ${ }^{2,10}$

Infrastructural developments and investments into telecommunications with an emphasis to internet access have been on the rise in Zimbabwe. Companies like Liquid, Zimbabwe on Line (ZOL) and TelOne have been on the front to making sure that Zimbabwe is highly connected. The Zimbabwe Freedom House (2015) furthers notes that no websites were blocked or filtered in Zimbabwe during the coverage period. Access to social media platforms such as Facebook, Twitter, and YouTube and international blog-hosting platforms are all freely available, and accessible at relatively low costs. Though in Zimbabwe the use of Facebook and Twitter for political engagements has been high and effective, other social media platforms like YouTube and Instagram aide in the posting and uploading of audios, videos and pictures.

\section{Facebook}

Initially came as a social platform and became popular around 2008. People connected and engaged in various social discourses. The platform connected people and made it possible to discuss issues with a wide audience, this made easy the quest for people to discuss and comment on political issues around them. Political activists started to exploit the platform to tell their stories which would reach a wider audience. In Zimbabwe around 2011 and towards the 2013 harmonised elections the use of Facebook to traffic political views was on the rise. Mainly because of the restrictions on the dissemination of information through the state owned television station and state controlled newspapers, people resorted to Facebook, for creation and dissemination of news and ideas. People would now criticise the government and express their views on daily issues. Facebook, as a networking site, has provided a platform for deep political engagement and the youths have embraced political consciousness due to social media. Studies claim digital media to be a potentially powerful tool for spreading democracy, encouraging political participation; carrying forward social justice and empowering civil society. ${ }^{40}$ Many had found a platform to offload their political burdens. With a backdrop of media censorship and monopolies which allowed only the stories which were deemed favourable to the ruling party, people found solace on Facebook as an alternative public sphere to actively participate in political discourse. Robust engagements were made, people poured out their hearts and aired their opinions on the platform. 
The famous "Baba Jukwa" page boasted of about 400000 followers at its peak. This page was being operated by a Faceless user who purported to be representing a gang of ZANU-PF rebels called "Vapanduki" a Shona name for rebels. This page mainly targeted ZANU-PF heavy weights, exposing their heinous past as well as exposing the plans to kill opponents and to steal the 2013 election. It gave chilling accounts on how people were abducted and subsequently killed by state agents. "What truly caused the death of Retired General Solomon Mujuru remains an issue of important national inquiry. Some of us who are in the know find it difficult to suppress that information and it is high time the truth has to come out," wrote Baba Jukwa in 2013. According to the Business Insider 18 July 2013, regardless of who they are, Baba Jukwa certainly seems to know a lot. The account would on a daily basis publish tales of official corruption and brutality, often leaving the phone numbers of politicians so that readers can call them to complain. The publishing of politicians' phone numbers and details left Josiah Mahovoya (38) in the hands of police a day after sending unprintable vulgar messages to Cde Chihuri and Cde Nduna. According to The Herald 31 July 2013, in passing the sentence Ms Gofa, the magistrate, said superiors should be given the respect they deserve. "The accused person committed a very serious offence by insulting those in the higher offices. The manner in which he committed the offence shows premeditation. It also contributes to public violence through inciting people to engage in violence. The court should be found sending the right message to the accused and would-be offenders," she said.

Baba Jukwa Facebook page also hogged the limelight in 2013 when on claiming he is a "concerned father, fighting nepotism and directly linking the community with their leaders, government, MPs and ministers", Baba Jukwa gained credibility after posting predictions about events that later happened. Baba Jukwa attracted a huge following; the page became one of the most trusted sources of news in Zimbabwe. The mysterious and enigmatic owner of this page convinced Zimbabweans that he had credible inside information of the power struggles and the impending implosion within ZANUPF. The page warned Chindori Chininga, and gave details of a plot to assassinate him by ZANU-PF's disgruntled leaders among them former Minister Saviour Kasukuwere. Baba Jukwa's warning and prediction came to pass as Chindori Chininga died in a car accident on 19 June 2013 a few days later. This attracted the attention of many Zimbabweans and the page became a feeding trough for Zimbabweans, especially those who belonged to the opposition side. Social media became popular, people believed in its powers to reach out and attract the attention of many. The brazen manner in which Facebook was used by Baba Jukwa to expose ZANU-PF was never heard of in Zimbabwe.

Through social media Zimbabweans managed to successfully penetrate into ZANU-PF's affairs and politics was discussed on this platform. It, however, had its casualties, as some fell prey to the security forces when they made comments which the state deemed sensitive. This social media drive had a lot of victims. People were still learning about the risks of using social media. Some made nasty comments and they would be tracked down by state security agents. Baba Jukwa had been witty enough to make sure that his identity remained unknown (even to this day), but the average, naïve Facebook user would participate with an account that has all his true identifications. People were harassed and threatened, many were victims. There was, however, a rise in the operation of Facebook Accounts with fake identification details after people realised how dangerous the Facebook corridors had become. Pages like "NIKUV RIGGINTON", "Small house ya Baba Jukwa" among other pseudo accounts began to sprout. People had mastered the art of hiding an identity to tell their story and to speak their mind. It can be argued that people learnt their lesson and had to follow Baba Jukwa's way of operating on Facebook. Information was posted, but the people behind all information or sensitive comments made sure that their identities remained a mystery.

In early July 2013, Baba Jukwa supposedly carried an online survey on who would be the next president after the elections. $10 \%$ of the respondents named Mugabe as the possible winner giving Tsvangirai a wide margin of $75 \%$. MDC leader Welshman Ncube garnered $3 \%$ of the vote while ZAPU leader (intelligence supremo) Dumiso Dabengwa got $1 \%$ (https://www.pindula.co.zw/Baba_Jukwa). The massive response to this online survey is a clear indication of how social media had recruited people to its political corridors. Political narratives had taken a new dimension, taking everyone on-board, thereby giving democracy an urge. It also equipped people with survival skills on social media, many people began to create ghost accounts specifically to comment and participate on social media political platforms. His following on Facebook was reflective of people's embrace of social media platforms as an alternative public sphere.

When one looks at the impact of the Baba Jukwa files on Facebook, it can be concluded that it was a game changer in the political narratives of the land. It challenged the traditional ways of doing business, it torched corners traditionally regarded as sacred, and it brought many things to light. People were informed; they no longer relied on the biased narratives by the state broadcasting agents. The use of social media to reach out to would be voters made a historical impact to Zimbabwe. However, the page raised hopes of Zimbabweans and of opposition party players to unrealistic levels. People believed everything posted on this page, mainly because it had made many correct predictions, people thought it was immune to mistakes and misjudgements. People were so excited to a point of failing to see the line between facts and personal opinions. People thought that the in fights in ZANU-PF which Baba Jukwa had noted were going to cripple the ruling party, the online poll survey placed Tsvangirai at $75 \%$ against Mugabe's $10 \%$. This was a white wash sort of an election and it gave an impression that so little a work was needed.

\section{An Editorial comment by Dinizulu Mbikokayise Macaphulana on New Zimbabwe reads:}

The opposition was excited about this entity to the extent that they became assured of its support and that it would secure their victory after the election. The entity kept the opposition assured by praising them here and there, and warning them of this and that. Now, here is the plan, if the opposition had won the election, a group of Zanu-PF strong ones were going to make an appearance and an announcement about themselves as the Baba Jukwa element and demand their share of power from the opposition with part of the army and some security elements on their side. The opposition were going to be forced to share power, in reality with Zanu-PF again. The above analysis seems to suggest that social media was used to manipulate and beguile the desperate Zimbabwe opposition party and its legion of supporters. Some even argue that, it was a plot by ZANU-PF to mislead supporters of the opposition. They were made to believe that dislodging ZANU-PF had become a simple task; they were made to believe that they needed not put maximum effort. Baba Jukwa made it sound like ZANU-PF was already on its knees and that the opposition 
had a small task in the elections ahead. The above argument suggests that social media was again manipulated just like the traditional media outlets. It was employed to send people to the wrong direction with so much energy. The opposition fell heavily to ZANU-PF on the 31 st July 2013 election despite all the assurances from social media.

\section{An editor for global black history news site had this to say:}

Criticism regarding Baba Jukwa has surfaced since he promised change that never came in the July 31 st election. He seemingly gave Zimbabweans who have access to Facebook 'false hope' regarding the elections. There is speculation of the suspicious, faceless character and some see him as a Trojan horse planted by ZANU-PF as a weapon of mass distraction to enable them to spy on the people who do not support them. In other words, it seems social media had been manipulated; it had been used as a tool to way lead enthusiastic supporters by giving them a false hope based on a blind submission. People were made to believe without making sober reasoning, they believed too much in a 'Faceless Messiah', whose correct predictions had made everyone to believe that he was one with them. From Baba Jukwa came Itai Dzamara, a veteran Zimbabwean journalist in 2014. He created the \#OccupyAfricaUnitySquare Facebook page, which he used to openly criticise the government of former president Robert Mugabe. He became famous when he hand delivered a petition to the former president's offices. He began to mobilize protesters through his personal Facebook page as well as the \#OccupyAfricaUnitySquare Facebook page he had created. People had learnt of the effectiveness of Facebook from various previous engagements, and Itai Dzamara's initiative became popular. On one of his Facebook posts Itai said "We occupied Africa Unity Square today, yet again forced the state to respond, and, yet again, demonstrated our goodwill by agreeing to negotiate. We are the people! We are the numbers!" Again we see the aiding power of social media in political mobilization of activists. People responded to his calls on Facebook and they came in numbers to occupy the premises. ${ }^{9}$

On several occasions Itai had clashes with the police and state security. He would always share pictures of various confrontations and even of the aftermath of a police brutality. Social media helped him tell his story with the state security. He was beaten on several occasions, sometimes even hospitalized. He would post all these pictures on Facebook, and Human Rights activists became aware of his plight. Had it not been for social media, Itai's struggle with the state could have gone unnoticed. Social media was a vehicle and conduit that transported awareness far and near ends. The state's brutality and abuse of human rights freedoms on Itai's case was exposed. Social media enabled political activists like Itai Dzamara to document their activities and to share with world their experiences. This initiative even attracted well-wishers and sponsors who started funding the activist so that the Occupy Africa Unity Square movement had food and necessary accessories.

Social media put Itai Dzamara on lime light, so much that when he was abducted the news spread easily. The news was put on social media and people expressed their anger towards the government which everyone believed that it was responsible for Itai's abduction and disappearance. Human Rights movements and people in general demanded answers from the government. The pressure was intensive to the extent of forcing ZANU-PF politicians like Professor Jonathan Moyo and Energy Mutodi to respond on social media. Social media in this particular case was a tool used to demand responses from government by the people of Zimbabwe. Human rights violations and police brutality was beamed to the world through social media. The government was exposed and people through this platform discouraged Zimbabweans from supporting ZANU-PF. Following the above, ZANU-PF through Professor Jonathan Moyo tried to exonerate the government by distancing it from Dzamara's abduction. He suggested that he may have faked the abduction and crossed the borders into neighbouring countries. The response did not help that much, the damage had already been done; social media had spread the news including the details of the vehicle which was said to have been used to abduct him. Social media equipped people with the truth so much that it was no longer easy and possible to spin and do a propaganda job on any incident. People had knowledge of how the state security had been dealing with Itai Dzamara from day one; they were following the events with much interest so much that any narrative that would seem to suggest that the state was not involved could find no taker. Such was the effect of social media to Itai Dzamara's case. Unlike other abductions which are said to have happened before the use of social media, Itai's caught the attention of many and the state was exposed big time. Political activism was made simple by the use of social media in Zimbabwe. One would launch an idea on social media with consistency and tenacious determination and ultimately the idea would get the attention of the people who would spread it and pledge their support. It seems the platform was created and all courageous individuals seized the opportunity and changed the political landscape.

Partson Dzamara, brother to Itai had to take the cue to pick from where his brother had left the fight with Zimbabwean politics. Partson used social media to continuously asking the authorities to give Zimbabwe a convincing explanation as to the whereabouts of his brother. On 15 November 2016 Partson wrote: We are calling on Zimbabweans from all walks of life to join us as we register our displeasure over the state of affairs in our nation. The time for us to draw a solid line in the sand has come. Cognisant of the fact that Mugabe and his minions won't listen to our outcry, we must speak to them in their own language. We must get into the streets and tell them we are tired of their misrule, leadership failure, corruption, and Zanu PF-made poverty. He now called people to take the fight to the streets and not only social media. This is a clear indication that social media was pivotal in mobilizations of protests. Social media was a great enabler towards the challenging of political opponents without necessarily facing them directly. Debates on whether Face book is public or private space continue. Agendas were set and plans were made on social media to the effect that people would respond with a clear vision of what was to be accomplished. With its population of marginalised young people, Africa Unity Square was a good place to start a revolution. At the time, the Arab Spring had planted seeds of fear that similar protests might happen in Zimbabwe. Mugabe was on August 262016 quoted by Reuters saying: "They are thinking that what happened in the Arab Spring is going to happen in this country but we tell them that it is not going to happen here," Mugabe told state television, referring to a series of uprisings that toppled leaders across the Arab world. Partson wrote several letters to the police demanding answers over the whereabouts of his brother. A Facebook page titled Bring Back Itai Dzamara Now was launched and people shared the page thereby spreading the issue. The page to date has about 2600 Likes and 2686 followers, both nationals and internationals. 


\section{Pastor Evan Mawarire: further analysis}

Another social media warrior who made history through Facebook is Pastor Evan Mawarire (as earlier described and chronicled). The cleric launched "\#ThisFlag" movement and it spread like wild fires through the social media and eventually down to the streets of Harare and the courts of the land. Pastor Evan Mawarire used Facebook live application to address Zimbabweans on social media on what he called a social and economic crisis in the country. The video he posted on 20 April 2016 had 100000 views in a short space of time and the video was being shared on Facebook and WhatsApp. This grew into a movement instantly and Pastor Evan had a following that would wait for his motivational recordings. After watching the videos, people from all corners of the country started posting their photos with the national flag. Social media was awash with pictures of Zimbabweans and their flag. Social media had made another impact, it shows that it had reached many and people showed that they were ready to take it to the next stage if called to. On 6 July 2016, he successfully organised a national stay away with the majority of working Zimbabweans, formal and informal, around the country heeding his call to stay away from work in a bid to make government respond to pleas for better governance. Mawarire called for people to stay away from work peacefully and to not engage in any violence.

Mawarire managed to take people to the streets in their numbers through social media. He was obeyed, his commands were obeyed, and he brought business to a standstill when he called for a stay away. It was a resounding success, thanks to social media. When he called for a second shut down from 13-14 July 2016, the state responded by calling him for question a day before the stay away. Evan shook the state via social media, he managed to convince people that they needed to take the activism to the streets and the people's response showed that social media was a useful tool. He handed himself to the police, but before he did that, he made sure he had updated his followers on Facebook so that everyone knew his whereabouts. He did that via a pre-recorded video that Mawarire himself recorded so that it could be released if he got arrested or abducted or if something happens to his life. He then handed himself over to the police for questioning on the morning of 12 July 2016. He was charged with Section 36 of the Criminal Law (Codification and Reform) Act Chapter 9:23 for "inciting public violence and disturbing peace."

Considering the foregoing revelations, social media had again in this instance exposed the state, putting them and Mawarire at a spot where all political stakeholders in-land and abroad could clearly observe the happenings. Everyone knew where Mawarire was, with his legion of Facebook followers taking the videos to other social media platforms such as WhatsApp and Twitter. Political activists took the opportunity to also mobilize people to demand the release of Mawarire. Social media news sites such as Zim Eye, Nehanda Radio and many others started doing some live online interviews calling people to air their views. The atmosphere was tense; people could no longer be suppressed because social media had broken the barriers. The repressive cords traditionally employed to people who would dare challenge the government of the day had been broken down. Freedom had come loaded on social media, enough for every interested person to have a fair share. The matter was a public spectacle due to the publicity it got from social media.

On the 13th of July 2016, Mawarire was taken to court to appear before a magistrate. One hundred lawyers from the Zimbabwe Lawyers for Human Rights offered to represent him. This was historical! Word went viral mobilizing people to come to the courts to support Mawarire and the people responded massively. The politics of the day faced a great hurdle and the state's sincerity to offer democracy to its citizens was put to test. The people of Zimbabwe came in their numbers and filled the court room while some were outside in the courtyard singing and praying. The police had to take Mawarire back to Harare Central Police station amid fears that the crowd that had come to support him might turn violent. Those at the courts continued to take pictures and posting them on Facebook with some being uploaded on WhatsApp calling more people to join them. There were delays by the courts for the trial which was scheduled for $11 \mathrm{am}$ in an attempt presumably to frustrate the gathered mob and make them leave the premises. The more they delayed the trial the more the people flocked the court. People from all racial backgrounds and social standing, especially those from the church came to show solidarity for Mawarire the hero of the moment. Popular figures such as Tehn Diamond, Takesure Zamar Ncube, Tudor Bismark, Shingi Munyeza, Nelson Chamisa and Jestina Mukoko were part of the crowd. Prayers were made for the Pastor and religious songs were sung throughout the court proceedings. There was also heavy police presence amid fears that violence would break out but people were encouraged to desist from violence in respect of what Mawarire advocated for. When Mawarire was released the gallery broke into song singing a church hymn of thanking God (as detailed earlier). The United States urged Zimbabwe to end arbitrary arrests and intimidation of political players as the country braced for the trial of prominent preacher Evan Mawarire for alleged treason. An online news site Bulawayo 24 carried the story on America's comments on the issue. The story was also put on Facebook for everyone to see. Below is the statement as quoted by Bulawayo 24: The United States is monitoring the trial of Pastor Evan Mawarire, and calls for an end to arbitrary arrests and intimidation for political purposes, the US embassy said in Harare ... We support freedom of expression and the right of peaceful assembly. We support freedom of expression and the right of peaceful assembly. (Trumps administration is monitoring the trial of Evan Mawarire, Bulawayo 24, published: September 25, access dated: December 07, 2018).

This shows that the issue had spread to the international stakeholders and social media helped in telling the protesters the impact this issue had. The moment an issue spreads like this, it means the transactions of that case is widely monitored. Social media made a breakthrough beyond the limitations of spreading political issues traditionally imposed on the people of Zimbabwe.

The trial eventually started at $2: 15 \mathrm{pm}$ with the state changing the trial charges from "inciting public violence and disturbing peace to subverting a constitutionally elected government". All this was a known trick used by the state to force people like Mawarire to stop the protests and even abandon such projects for fear of the wrath of the law. In this case social media was awash with debates on the matter giving the state no opportunity to molest the law and the people of the land. Social media enabled people to pile pressure on the state to free Mawarire. Mawarire appeared in court with the Zimbabwean flag on his shoulders. Mawarire's case was dismissed by the Magistrate presiding over the case as it was a violation of the constitution of Zimbabwe. This was a landmark win for the people, and testament to the effect of social media on the politics of the land. It had been used widely to alert citizens, to mobilize them, and to strengthen them on their quest for freedom of expression. Thus it became a trusted and credible platform to push an agenda as well as to reach to the masses. Of notable significance is the use of social media to get 
people from their computers and smart phones into the streets. The coming of people to the streets in response to social media initiatives showed that people had found another channel to pursue their political interests unhindered and uncensored.

\section{Twitter}

Tweeter became popular in Zimbabwean politics discussions in around 2016 and grew to arguably outdo Facebook in the run up to election 2018. Jacquelin Kataneksza said "The changes in Zimbabwean political culture that have resulted from the cumulative effects of all these varied digital actions cannot be ignored. Towards the end of Mugabe's reign, social media platforms were mainly for the opposition movements and personalities, but a drastic shift took place towards the 2018 harmonized elections, which saw the ruling party ZANU-PF pitching their tents on social media streets. President Emmerson Mnangagwa himself had his twitter account verified and refined to make sure he is noticeable. Many political opponents made sure that their presence too is felt. Under President Emmerson Mnangagwa's leadership, ZANU-PF brought a new energy to run social media accounts that were more on a persuasive trajectory as opposed to the biased and one sided approach on the traditionally state controlled media"

\section{Zimbabwean Twitter is shifting politics}

By Jacquelin Kataneksza: An article by Partson Dzamara in News Day of 30 May 2018 showed the state of affairs in the twitter corridors. Partson wrote: "This article is written against a background of Zanu PF's presidential candidate for the 2018 plebiscite, Emmerson Mnangagwa recently unleashing his party youths to be vigilant on social media, instructing them (Rakashai vanhu pa sosho media) "Clobber them on social media". The President had told his youth supporters to be actively involved in the social media debates and defend the party ideology. This shows that the party was living up to the realities of the time. They had realised how powerful social media was in making political persuasions as well as furthering them. Though opposition opponents like Partson Dzamara took it to mean that the president was encouraging violence on social media, it can be easily concluded that he was simply unleashing them to win debates on behalf of the party.

According to an article by Jacquelin Kataneksza "It's been claimed that ZANU-PF paid unemployed, computer literate supporters to flood social media platforms with attacks and counter-attacks targeted at overwhelming a poorly resourced opposition." The authenticity of the above claim is debatable, but the fact that ZANU-PF had a crafted and coordinated social media crew is true. They ran their accounts as individuals, but they would say almost the same thing from different fronts. The opposition, on the other side took a counter measure; they also stood to defend their movement. The ruling party's "Varakashi" took on Chamisa supporters known as "Nerrorists" (after Chamisa's nickname, Nero) in a series of online propaganda battles. The marked upsurge in the tactical use of inflammatory language, and fear mongering as well the distribution of fake news and doctored images, arguably buoyed some candidates while bringing others down. On Election Day, all three platforms were used by people chronicling their voting experiences. And the violent aftermath of the election that left several people dead played out online even as it played out on the streets. There was a lot of information circulated on social media.

Early morning on 01 August 2018 at 02:37 am, Nelson Chamisa took his message to twitter and said: "Thank you Zimbabwe... I'm humbled by the support you have given to me as a presidential candidate. We have won the popular vote. You voted for total change in this past election. We have won this one together, No amount of results manipulation will alter your will...\#Godisinit.”(@nelsonchamisa) At around 02:50 am on 01 August 2018 Chamisa posted the following on his twitter handle: "Winning resoundingly...We now have results from the majority of the over 10000 polling stations. We've done exceedingly well. Awaiting ZEC to perform their constitutional duty to officially announce the people's election results and we are ready to form the next gvt. \#Godisinit". On the same date 01 August 2018 at 1:09 pm, President Emmerson Mnangagwa also took to twitter and said "At this crucial time, I call on everyone to desist from provocative declarations and statements. We must all demonstrate patience and maturity, and act in a way that puts our people and their safety first. Now is the time for responsibility and above all, peace. (@edmnangagwa). The notion sent by Nelson Chamisa's tweet was that election manipulation was likely and also that he had won the race, this was in violation of the Constitutional Act, which prohibits the premature announcement of election results. This was an abuse of social media, a manipulation of the tool knowing very well that it was effective. As a media outlet, social media was used by both political parties in a biased manner. Tendai Biti ${ }^{41,42}$ was also embroiled in controversy as he held a press conference and allegedly announced that Nelson Chamisa had won the elections and also that ZANU-PF was in an attempt to rig and steal the election. The videos were sent on twitter and the masses were stirred. Some party hardliners like Happy more Chidziva took to twitter and invited party supporters to come at the party headquarters to celebrate the alleged victory.

Social media contributed a lot to the happenings of the violent protests that erupted in Harare on 1 August 2018. People were demonstrating against an alleged vote stealing and they wanted their preferred candidate announced and declared winner. Tempers were high, and a lot of unauthenticated news was circulating on social media. When the army was deployed, social media was awash with the news. People posted videos and photos of soldiers in action as well as of the victims. The news also spread and the international world got the story and they aired their views on the developments. The article argues that the rise of internet use, access to mobile phones and mobile network coverage offered hope for access to information, freedom of speech and association referred to above. We also argue that social media platforms have challenges of unverified, exaggerated, unauthentic and sometimes fake content; consequently misleading citizens.

People became intolerant of each other's views on twitter, so much that it was no longer safe to air one's views especially those contradicting the popular view. It became dangerous to belong to either side, there was a lot of verbal abuse and verbal attacks on opponents. This could also justify the existence of a lot of ghost accounts on twitter; it could be that people had to hide their identity for their safety. The fear of reprimand, harassment and insults was also based on the statement issued by the Army Commander Lieutenant-General Phillip Valerio Sibanda published in The Herald of 5 August 2016. He said the following: "As an army, at our institution of training, we are training our officers to be able to deal with this new threat we call cyber warfare, where weapons, not necessarily guns, but basically information and communication technology, are being used to mobilise people to do wrong things. We will be equal to the task when the time comes." The above statement sent a clear message that 
the security sector had also considered active involvement on social media political issues. Their aim was to "deal" with this new threat as the Commander highlighted, and this shows that it could be very difficult to participate on political discourse on either Facebook or twitter. People had to hide behind fake accounts, and the fake accounts became cauldrons of various nefarious activities by both the ruling party and opposition party supporters. Hate speech, name calling and all sorts of denigrating behaviours have been manifested on social media. Social media has also been critical in exposing corruption and bringing to light untold transactions and murky dealings of the elite and the big fish. Post July 2018 election, President Mnangagwa reiterated on his fight against corruption and any retrogressive behaviours that would cripple the economy. Corruption in Zimbabwe had reached alarming levels during the Mugabe era, and when President Mnangagwa declared war against it, people were willing to help him as well as to test the sincerity of his public statements against corruption. William Mutumanje popularly known as Acie Lumumba in the political circles as well as on social media is among the social media warriors who took corruption expositions to social media.

In a letter, Finance Minister Prof Mthuli Ncube announced the appointment of Lumumba on 20 October 2018as the new spokesman for his ministry. The letter was widely circulated on social media and was also widely criticised on social media. In no time, news went viral that Lumumba had been unprocedurally appointed and that his ouster was imminent. Lumumba took to Facebook and Twitter to expose people who were behind his sacking as well as behind the financial crisis in the land. He alleged that Queen Bee leads a corrupt cartel that has captured some senior politicians, and named certain directors at the Reserve Bank of Zimbabwe (RBZ), claiming they were part of a syndicate causing untold suffering in the country. Consequently, and because of Lumumba's revelations four directors at the central bank were suspended pending investigations. Lumumba's story was widely believed, people started to question the sincerity of President Emmerson Mnangagwa and his government in its fight against corruption. This did not only expose corrupt cartels, it also exposed the state as well. Social media in this case was used to even influence the state to take action see. The above news site suggests that Lumumba's social media antics had pressured the President to make the officials suspended through RBZ governor. Social media again has been used to expose the rot in Public Service, with the latest being the corrupt engagements by Public Service Commission paymaster at the Salary Services Bureau, Brighton Chiuzingo, and general manager human resources only identified as E. Chigaba, on allegations of abuse of office and mismanagement. According to an article by Matthew Takaona. Brighton Chiuzingo, the chief paymaster at the Government Salaries Service Bureau (SSB) had been suspended from work without pay on allegations of making arbitrary allowance and salary increases of $40 \%$ for himself and collecting back pay of $\$ 6600$ backdated to January 2018. This rot had been exposed by one Prisca Mutema on 06 December 2018 on her Twitter handle (@PriscaMutema2). She wrote "This is Brighton Chiuzingo, Zimbabwe Gvt Paymaster General. He is a thief \& a major reason why gvt spends $95 \%$ of its budget just on salaries. He is also part of a cartel that involves the Registrar General's \& the Immigration Dept. The cartel's business is fraud." She further said "This is Ngoni Masoka, former PremSec in the Public Service Ministry \& Chairman, Chief Corruptor \& Godfather of (NSSA). Since 2014, these 2 have stolen millions of US\$ thru gvt payroll \& NSSA. He's also reason $95 \%$ of gvt budget is spent on salaries. She went on a 14 thread twitter laying bare facts backing her exposition. The tweet had about 250 retweets from her twitter followers, and the issue was blown in a day. The Herald of 07 December 2018 carried a story to the effect that government had suspended Brighton Chiuzingo, a day after social media had blown the whistle. This shows that the political narratives of the land have seen the coming in of a new player which is social media. Social media has been used for the fast spread of news in a way that leaves the traditional media outlets behind. News now spread faster through social media, and people have resorted to believing more on social media for news than any other source. As discussed earlier in the paper, Prisca Mutema who has exposed the Public Service rot is controversially believed to be a ghost account but revealing the sober truth obtaining in the country.

\section{Conclusion}

It is important to highlight that the surge in the use of internet and ICT products led to the widespread use of social media platforms such as Facebook, Twitter, and YouTube in Zimbabwe. These social media platforms became a launch pad for political activism, civil resistance and exposure of corruption in Zimbabwe which include; \#ThisFlag, \#OccupyAfricaUnitySquare, \#Tajamuka/Sesijikile, \#ThisGown, Baba Jukwa among others. It is also argued in this article that social media provided a discursive space for ordinary citizens' voices to articulate their problems and to challenge the excesses of the government, which is epitomised by endemic corruption and bad governance and has caused massive unemployment and has plummeted the Zimbabwean economy. The paper concludes that the coming in of social media changed the landscape of political discourse. The change brought about by social media started as freedom of expression on networks which eventually spilled into the streets. Social media has been an effective tool in evading and ducking of the state's involvement in information dissemination. The vices of the state in manipulating media outlets and influencing their work was diluted and made less effective through the use of social media. The people of Zimbabwe had been under suppression for too long under the Mugabe era, so much that when social media came it became so popular a public sphere which was greatly embraced. The posting of videos and photographs on social media gave people news as the events unfolded giving less room for the spinning of state controlled media. Live feeds and live streaming made sure that the news is not doctored or cooked. However, social media platforms also opened doors for bullies and warmongers. The attack one would get from opponents after giving their side of an issue or after showing that they support a certain political party was not only untoward, but a sign of deep sitting rage among Zimbabweans. It used to be that supporters of the ruling party would bully opponents openly, but on social media both parties exhibited bully tendencies and intolerance. This article also concludes that journalists in the mainstream media now largely rely on social media as sources for their stories in newspapers or broadcasting.

\section{Acknowledgments}

None.

\section{Conflicts of interest}

The author declares there are no conflicts of interest.

\section{References}

1. Mungwari T. Representation Political Conflict in The Zimbabwean Press: The Case of The Herald, The Sunday Mail, Daily News \& The Standard, 1999-2016. Unpublished PhD Thesis: UNISA, Pretoria; 2017. $272 \mathrm{p}$. 
2. Moyo C. Social Movements, Social Media \& Civil Resistance in Zimbabwe, 2016-2017: Lessons for the Future. The International Journal of Humanities and Social Studies. 2018;6(2):137-145.

3. Chiluwa L. Social Media Networks and Discourse of Resistance. A sociolinguistic CDA of Biafra online discourses. Discourses and Society. 2012;23(3):217-244

4. Institute of Security Studies. Encouraging Political Participation in Africa: The Potential of Social Media Platforms. Pretoria: Institute for Peace Studies; 2012. $12 \mathrm{p}$

5. Breuer A. The Role of Social Media in Mobilising Political Protest: Evidence from the Tunisian Revolution. Berlin: Germany Development Institute; $2012.47 \mathrm{p}$

6. Stork S. The Role of Social Media in Political Mobilisation: A Case Study of the January 2011 Egyptian Uprising. MA Dissertation. 2011. 51 p.

7. Harvey K. Libya. Encyclopaedia of Social Media and Politics. California. CA: SAGE Publications. 2014. 1556 p.

8. Willems W. Social media platforms, power and information in Zimbabwe's recent elections. London: LSE; 2016. 285 p.

9. Moyo C. Dear Zimbabweans, we have nothing to lose but freedom to gain. Nehanda Radio. 2017.

10. Gukurume S. This Flag and \#This Gown Cyber Protests in Zimbabwe: Reclaiming Political Space. African Journalism Studies. 2017;38(2):4970.

11. Fraser N. Rethinking the Public Sphere: A contribution to the Critique of Actually Existing emocracy. In Habermas and the Public Sphere. In Calhoun C, editor. Cambridge, MA: The MIT Press. 1992. pp. 109-142.

12. Squires CR. Rethinking the Black Public Sphere: An Alternative Vocabulary for Multiple Public Spheres. Communication Theory. 2002;12(4):446-468.

13. Bosch T. Youth, Facebook and Politics in South Africa. Journal of African Media Studies. 2013;5(2):119-130.

14. Mare A. Facebook, Youth and Political Action: A Comparative Study of Zimbabwe and South Africa. PhD dissertation: Rhodes University; 2015. $228 \mathrm{p}$.

15. Mutsvairo B, Sirks L. Examining the Contribution of Social Media in Reinforcing Political Participation in Zimbabwe. Journal of African Media Studies. 2015;7(3):329-344.

16. Mutsvairo B. Perspectives on Participatory Politics and Citizen Journalism in Networked Africa: A Connected Continent. London: Palgrave Macmillan; 2015. 15 p.

17. Ngomba J. Social Media and election Campaigns in Sub-Saharan Africa: Insights from Cameroon. The Routledge Companion to social Media and Politics. In: Bruns A, Enli G, Skogerbo E, editors. London: Routledge; 2016. pp. 447-459.

18. Olorunnisola AA, Douai A. New Media Influence on Social and Political Change in Africa. Hershy, PA: IGI-Global; 2013. 518 p.

19. Bayraktutan GM, Binark T, Comu B, et al. The Use of Facebook by Political Parties and Leaders in the 2011 Turkish General Elections: Quantitative and Qualitative Content Analysis. In: Social Media in Politics. Cham: Springer; 2015. pp. 165-199.

20. Bennett WL. Changing Citizenships in the Digital Age. In: Civic Life Online: Learning how Digital Media Can Engage Youth. Cambridge, MA: The MIT Press; 2008. 24 p.

21. Borah P. Facebook use in the 2012 USA Presidential Campaign. In: Patrut B, Patrut M, editors. Social Media in Politics. Cham: Springer; 2014. 382 p.
22. Dezelan T, Vobic I, Maksuti A. Twitter Campaigning in the 2011 National Election in Slovenia: Strategy and Application of the Twitter Social Media Outlet in party election campaigns. In: Patrut B, Patrut M, editors. Social Media in Politics. Cham: Springer; 2014. pp. 141-163.

23. Mungwari T. The Politics of State Capture in Zimbabwe. International Journal of Research and Social Science. 2019;3(2):1-13.

24. Moyo L. Blogging Down a dictatorship: Human Rights, Citizen Journalists and the right to communicate in Zimbabwe. Journalism. 2011;12(6):745-760

25. Hodgkinson D. The 'Hardcore' Student Activist: The Zimbabwe National Student Union (ZINASU), State Violence, and Frustrated Masculinity, 2000-2008. Journal of Southern African Studies. 2013;39(4):863-883.

26. Zeilig L. Student Politics and Activism in Zimbabwe: The Frustrated Transition. Journal of Asian and African Studies. 2008;43(2):215-237.

27. Raftopoulos B, Sachikonye L. Striking Back: The Labour Movement and the Post-Colonial State in Zimbabwe, 1980-2000. Harare: Weaver Press; 2001. $361 \mathrm{p}$

28. Chiumbu SH. Social Movement, Media Practices and Radical Democracy in South Africa. French Journal for Media Research. 2015;4(1):1-20.

29. Benkler Y. The Wealth of Networks. London: Yale University Press; 2006. $527 \mathrm{p}$.

30. Fatkin M. Social Media and Communication Theories. Start-Thinking. 2017.

31. Pan B, Crotts J. Theoretical Models of Social Media, Marketing implications, and future research development. In: Sigala M, Christou E, Gretzel U, editors. Social Media in Travel, Tourism \& Hospitality: Theory, Practice \& Cases. UK. Suney: Ashgate; 2012. pp. 73-86.

32. Aljazeera. Zim Social Media Freedom vs. State owned monopoly Aljazeera. 2013.

33. This Flag/Ifulegi Leyi/Mureza Uyu. 2017.

34. Mitra A. Voices of the Marginalized on the Internet: Examples from a Website for Women of South Asia. Journal of Communication 2004;54(3):492-510.

35. Chatterjee P. Reflection on 'Can the Subaltern speak?' Subaltern Studies after Spivak. In: Morris RC, editor. Can the Subaltern Speak? Reflections on the History of an Idea. New York: Colombia University Press; 2010. pp. 8-16.

36. Spivak GC. Can the Subaltern Speak? In Marxism and the Interpretation of Culture. Nelson C, Grossberg L, editors. Basingstoke: McMillan 1988. pp. 271-313.

37. Ranger T. Nationalist Histography, Patriotic History and the History of the Nation. Journal of Southern African Studies. 2004;30(2):215-234.

38. Tendi B. Patriotic History and Public Intellectuals Critical of Power Journal of Southern African Studies. 2008;34(2):379-396.

39. Manayiti O. ZANU PF plots counter protests. News Day. 2016.

40. Wang ZX. Social Media in Industrial China. London: UCL Press; 2016.

41. Tendi BM. Why a hashtag isn't enough for a revolution in Zimbabwe? Foreign Policy. 2015. 225 p.

42. Zeilig L. Struggle Reawakens in Zimbabwe. Green Left Weekly 2016;1103:15 